\title{
Prognosis and outcome of intensive care for very elderly patients
}

\author{
S Becker, J Müller, G de Heer, V Fuhrmann, S Kluge* \\ From ESICM LIVES 2015 \\ Berlin, Germany. 3-7 October 2015
}

\section{Introduction}

The proportion of elderly and very elderly patients is rising in industrial countries. Elderly patients are expected to outnumber younger age groups in the use of health services in the future. Since the prognosis of elderly patients is generally considered to be poor, the indication for ICU admission is kept very strict.

\section{Objectives}

The aim of this study was to analyze the characteristics and outcome of intensive care treatment of very elderly patients ( $\geq 90$ years), as this age group is growing rapidly and is becoming of increasing importance in intensive care medicine.

\section{Methods}

Monocentric, retrospective evaluation of patients aged $\geq$ 90 years admitted to the intensive care units at the Hamburg University-Hospital between 01.01.2008 and 30.6.2013.

\section{Results}

A total of 372 patients $\geq 90$ years were admitted to the intensive care units (ICUs). The majority (66.7\%) of patients were admitted because of an emergency, and of which, half underwent unscheduled surgery. 39.8\% needed support by mechanical ventilation and vasoactive drugs, $1,9 \%$ received renal replacement.

ICU and hospital mortality rates were $18.3 \%$ and $30.9 \%$, respectively. Mortality at one year after hospital discharge was $46.3 \%$.

Binary regression analysis revealed high SAPS II scores on admission and necessity of mechanical ventilation as independent risk factors for ICU-mortality.

$17.5 \%$ of patients had an advance directive.

Universitätsklinikum Hamburg Eppendorf, Intensivmedizin, Hamburg, Germany

(c) 2015 Becker et al.; This is an Open Access article distributed under the terms of the Creative Commons Attribution License (http:// creativecommons.org/licenses/by/4.0), which permits unrestricted use, distribution, and reproduction in any medium, provided the original work is properly cited.

\section{Conclusions}

Nearly $70 \%$ of patients aged $\geq 90$ years were discharged alive from hospital following treatment at the ICU, more than half were still alive one year after discharge. Nowadays, age no longer determinates admission to intensive care.

Published: 1 October 2015

doi:10.1186/2197-425X-3-S1-A367

Cite this article as: Becker et al:: Prognosis and outcome of intensive care for very elderly patients. Intensive Care Medicine Experimental 2015 3(Suppl 1):A367.
Submit your manuscript to a SpringerOpen ${ }^{\circ}$ journal and benefit from:

- Convenient online submission

- Rigorous peer review

- Immediate publication on acceptance

- Open access: articles freely available online

- High visibility within the field

- Retaining the copyright to your article

Submit your next manuscript at $>$ springeropen.com 